Österreichische Akademie der Wissenschaften / Austrian Academy of Sciences AAS WORKING PAPERS IN SOCIAL ANTHROPOLOGY Volume 26

\author{
John F. McCarthy \\ COMMUNITY LED DEVELOPMENT \\ AND VULNERABILITY IN A \\ POST-DISASTER CONTEXT: \\ CAUGHT IN A SAD ROMANCE
}
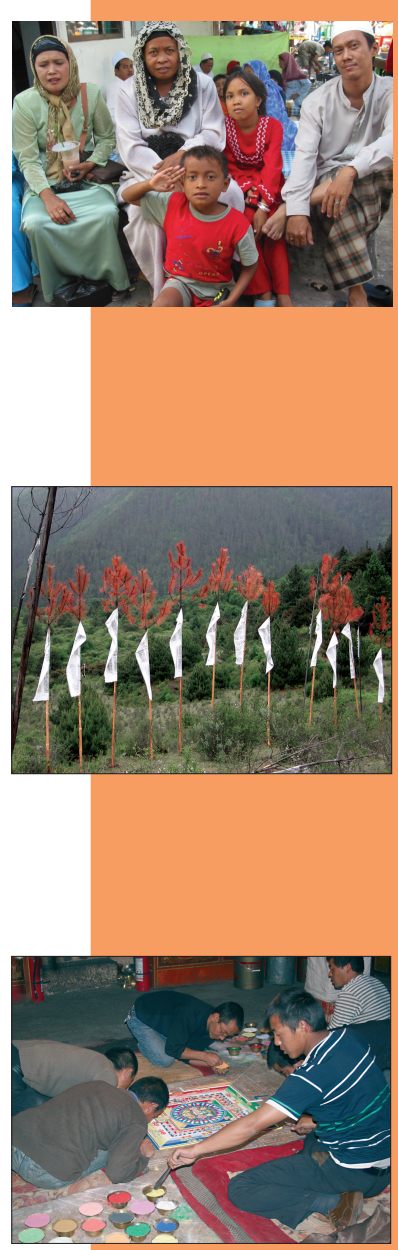


\section{AAS Working Papers in Social Anthropology / \\ ÖAW Arbeitspapiere zur Sozialanthropologie}

ISBN-Online: 978-3-7001-7318-2

DOI:10.1553/wpsa26

Wien 2013

\section{Editors / Herausgeber:}

Andre Gingrich \& Guntram Hazod

(C) Institut für Sozialanthropologie

Zentrum Asienwissenschaften und Sozialanthropologie

Österreichische Akademie der Wissenschaften

Apostelgasse 23

A-1030 Wien

Fax: 01/ 51581-6450

E-Mail: sozialanthropologie@oeaw.ac.at 


\title{
COMMUNITY LED DEVELOPMENT AND VULNERABILITY IN A POST-DISASTER CONTEXT: CAUGHT IN A SAD ROMANCE*
}

\author{
JoHN F. McCARTHY
}

\begin{abstract}
One reading of the social capital literature suggests that the networks and the social relationships which enable collective action can be used to address critical livelihood needs, even in disaster contexts. This paper concerns post-tsunami Aceh, where following the largest disaster in forty years, one of the biggest reconstruction programs in history implemented livelihoods projects, making use of community led recovery approaches. This paper finds that social capital ideas stabilized policy thinking, legitimized project interventions, and provided a template for project action. Examining the effects of community led approaches in two sub-districts eight years after the tsunami, it compares the few instances in which particular livelihood projects led to enduring forms of collective action, with the majority of cases, in which these approaches failed to address the underlying drivers of vulnerability. Community led policy narratives often do not match with the logic of social action embedded in local networked space. As interventions based on social capital ideas may have limited purchase in post-disaster contexts of this kind, efforts to address vulnerability in post-disaster contexts need to address drivers of vulnerability in agrarian livelihoods in a systematic fashion, moving beyond the narrowly focused community led livelihood interventions of post-disaster recovery.
\end{abstract}

\section{Introduction}

Policy discussions, project inteventions and a wide body of literature now focus on complex problems creating multiple shocks and stressors that generate disadvantage among large populations. In particular, flood, drought and other natural disasters, now exacerbated by climate change and conflict, have the potential to transform marginal forms of poverty, vulnerability or even food insecurity into chronic problems. When such problems come together in a catastrophic fashion, donors make large investments in humanitarian responses. Following the advent of a substantial body of work which advocates beneficiary participation in development (Hickey and Mohan 2005) and the "routinication of social capital" in public policy (Woolcock 2010), it is now conventional for interventions to "be designed to recognise, support and build on the strengths and capacities of those most likely to be victimised by the given crisis" (Anderson 2000: 6). Part of the narrative here is that, in the absence of effective forms of accountability within the state and through donors, better outcomes ensue when projects set up participatory structures to facilitate public scrutiny and accountability in both decision making and implementation. The paradox is that, despite the deployment of sufficient resources, the best of intentions and the application of such methodologies, in so many cases reconstruction (re)produces vulnerabilities without recovering pre-disaster levels of development (Blaikie 2009; Lyons 2009).

\footnotetext{
* The present contribution is based on a paper presented by the author at the Institute for Social Anthropology of the Austrian Academy of Sciences, Vienna, June 24 2013. The research for this paper was supported under the Australian Research Council's Discovery Projects funding scheme. The research was undertaken in collaboration with the International Centre for Aceh and Indian Ocean Studies (ICAIOS) and the author is particularly grateful to Saiful Mahdi for facilitating the research. A special thanks to Nulwita Maliati, Shaummil Hadi, Zuhri Azwar and Zahari Zen for their assistance and many insights as well as to the villagers in Aceh Besar for their hospitality and patience. Thanks also to Gerben Nooteboom and colleagues in RE\&AD at the Australian National University for comments on an earlier draft. The views expressed herein are those of the author.
} 
The 2004 tsunami was the world's largest natural disaster in forty years (Cosgrave 2007), devastating Aceh's west coast, with 130,000 confirmed dead and an additional 500,000 people displaced. Enormous resources were deployed on rehabilitation and reconstruction - in the developmental lexicon, "to build back better". Here "better" amounted to "improving infrastructure and adhering to social concerns such as reducing poverty, improving livelihoods and increasing equity" (Masyrafah and McKeon 2008: 28). Indeed, in the highly affected Indonesian province of Aceh, $\$ 7.5$ billion was spent on post-tsunami relief by more than 463 NGOs and donor agencies implementing projects, making Post-tsunami Aceh "one of the largest reconstruction projects ever seen in the developing world" (Masyrafah and McKeon 2008). The immediate post-tsunami crisis intervention is seen as successful, particularly as it provided emergency assistance, social protection during the immediate crisis period, and effectively rebuilt infrastructure (Webb 2005; Athukorala 2010). However, there is now ample evidence that persistent, high levels of longer term, chronic poverty and vulnerability created by the insurgency and the disaster remain (World Bank 2008).

Researchers have examined many different aspects of the physical, material and human response to the tsunami (e.g. Clark et al. 2010; Jayasuriya et al. 2010; Thorburn 2010). However, what are the enduring legacies of aid, long after the disaster - when the gaze of the aid industry has moved elsewhere? Little work has been done to understand the problem of persistent poverty and post-tsunami intervention outcomes in relational terms, while taking into account vernacular understandings. This paper will address the following questions: To what degree have social networks taken up the logics promoted by community based and community driven development (CBD and CDD) project interventions? In what ways has the idea of mobilising social capital through project interventions led to enduring collective action to address livelihood solutions? ${ }^{1}$

This paper argues that the gap between the intentions of interventions that attempt to mobilise social capital and the outcomes they achieved need to be understood in terms of the contradiction between, on the one hand, the logic of community led policy narratives, and on the other hand, the aid practices and situational logic that shaped attempts to assist communities. This gap emerges from three parallel sets of processes or practices. First, participatory livelihood thinking and social capital ideas clearly structured the intervention policy in Aceh, providing a template for addressing community needs. However, good policy may fail to provide a frame for understanding the drivers of poverty; and policy statements may neither provide a good guide for implementation, nor represent field realities (Mosse 2010). Indeed, a second set of exigencies shaped the activities of NGOs and donor agencies, which included: the transient nature of assistance; the kind of delivery mechanisms available; the exit strategies set into project planning; and the needs of donors and NGOs to achieve success. Negotiating rural development remains difficult, even more so when a tsunami follows a conflict. The complexity of the dynamics generating poverty, vulnerability and food insecurity ensures that linear programmatic approaches will face significant challenges, particularly when project templates leave structural and relational dynamics outside their technical

${ }^{1}$ Both CBD and CDD approaches aim to harness and "build" social capital, using social capital ideas as discursive justification for project interventions. While CBD has been defined as "an umbrella term for projects that actively include beneficiaries in their design and management" (Mansuri and Rao 2004: 1), CDD approaches tend to be involve more encompassing participant involvement in decisions regarding how funds are spent. CDD approaches involve two main components: facilitation and support for participation in the selection, design and implement of a development project and funding for the implementation of the project (King et al. 2010). Here I use the term community led to refer to the wider set of CDD and CBD approaches. 
framework for analysis and action ( $\mathrm{Li}$ 2007). At the same time, donor practices necessarily ran into a third set of factors for which neither participatory/CDD templates, nor post-recovery narratives, provided adequate explanations: Acehnese field realities. Given the strong inequalities, entrenched patterns of relational power, and disorganisation, fragmentation and trauma following the conflict and the tsunami, there was only limited potential for successful community based development approaches. This paper shows that a particular post-disaster situational logic-building on historical social relations and more than a decade of conflict - shaped modes of social action that occurred in networked space, affecting both what was desirable and achievable at a particular time. Significant reductions in poverty and vulnerability require broader and on going strategies of social policy and economic development in addition to the narrowly targeted community led livelihood interventions deployed here.

This study draws its conclusions from local qualitative studies in two heavily affected sub-districts on the west coast of Aceh Besar that are linked with a large scale quantitative survey (Kecamatan Development Program 2006), and a survey of indirect indicators of social capital within two sample villages (here labeled village 1 and 2) selected randomly from each sub-district. This approach bears in mind the conclusion of other researchers that the character of social capital tends to depend on historical and social context; that the search for generalised rules which correlate types of social capital with specific social variables has proved ineffective; and that indicators of social capital provide only a poor guide to the critical informal dynamics associated with collective action (Pelling and High 2005). Qualitative semi-structured interviews and focus group discussions were undertaken with village leaders, sub-district and district officials, local police and military officials, and customary leaders; as well as key village informants, World Bank and PNPM project facilitators, NGOs and local academics. The study also sought to complement the more extensive analysis of the challenges faced by donors in the post-tsunami context, in the process providing space for vernacular perspective of the participatory, CBD and CDD approaches deployed in Aceh.

The present paper pursues these questions in the following way. First, it undertakes a review of frameworks for analysing social capital and community based or driven approaches. Second, it analyses "successful" participatory livelihood and CDD projects in two sub-districts. Finally, it draws some conclusions regarding where elements of adaptive capacity - the ability to respond to vulnerability - emerged.

\section{The Romance of Social Capital}

Social capital-based approaches to community development have now become widespread. The original thesis argued that social capital not only facilitates collective action and economic development, but that it is ultimately the mechanism that connects the two (Woolcott 2010: 481). While articulated in various ways, the simple idea here is that the social capital embedded in participatory groups encompasses shared understandings of fairness, leadership, rights and duties, and ways of doing things amounts to something that can be built, tapped, used, or otherwise mobilised for developmental ends (Nakagawa and Shaw 2004). This has been taken up in community driven development (CDD) and social fund approaches which seek to get communities involved in choosing how funds might be spent, thereby developing interventions that more effectively support community development. The compelling prospect of "getting the social relations right" exerts an attractive power: the romance of mobilising social capital and thereby achieving much better developmental outcomes. 
Consequently, with renewed focus on "getting the social relations right", the success of projects has come to be seen to hinge on their ability to engage with the local social context. However, critics have found the concept of social capital slippery and highly contested (Woolcott 2010; Fox 2007). First, social capital can facilitate transactions among particular interest groups, while excluding other groups from access to resources (Cleaver 2005). In other words, social capital both helps and hinders advancement and dealing with collective action problems. Second, approaches using social capital ideas may tend to instrumentalise social life (Mosse 2004). Third, social capital approaches may sidestep structural questions of power and inequality, setting aside political economic relations from their "knowable, technical domain" of governmental practices (Li 2007: 231). Fourth, critics argue that the social capital approach fits with a form of poverty analysis that tends to cast responsibility for both poverty and poverty reduction on the poor themselves, setting aside the case for large-scale public action to engage with the drivers of poverty and vulnerability.

Despite these critiques, the questions raised by the social capital thesis - understood here as the networks and social relationships that facilitate collective action (Fox 2007: 142) - converge with an analysis of poverty in relational terms. The ability of individuals to leverage resources depends upon their access to particular social arrangements. While individuals with "wealth in people" will be relatively empowered, those who are most vulnerable tend to be those who are unable to make social claims or who have been deprived of a dependent status (Mosse 2010: 1158). This supports an analysis of how social inequality and risk are (re)produced within vertical and horizontal networks that facilitate (or not) access to entitlements. Engagements between communities, donors, and the state can then be analysed in terms of how resources and information flow, what dynamics shape access to external resources, and how internal community resources are mobilised.

2.1 Social capital, poverty and food insecurity in rural Aceh

A perusal of post-tsunami project documents points to the widespread utilisation of participatory $\mathrm{CBD} / \mathrm{CDD}$ lexicon. Project evaluations stress the "role of the community in building back better" - for instance in "community led and implemented village infrastructure projects" and "consensusbased village mapping processes" (BRR, $\mathrm{x}$ ). The key reconstruction agency, the BRR, noted that it explicitly intended the process of reconstruction to "strengthen social capital and community capacities", as well as "to innovate and improve public sector delivery and effectiveness" (BRR, 43). World Bank assessments also found that "social capital at the community level in Aceh is strong" (Kecamatan Development Program 2006, 72). Given that "social capital is widely accepted as one of the key pillars for empowerment at the local level and as one of the key ingredients for successful community development programs", this indicated an appropriate logic of intervention.

Fieldwork revealed particular patterns of network formation. The World Bank surveys had found high participation rates for social activities. Amongst comparatively homogenous, poorly educated rural communities, villagers intensively interact with family, friends or neighbours; for instance, routinely exchanging gifts, assistance and labour. However, closer scrutiny revealed that these horizontal networks which involved balanced forms of reciprocity were less uniformly strong. Interviews revealed that the conflict and the subsistence crisis had generated a breakdown in trust and reciprocity among some villagers: for instance, when people could not trust their neighbours during the conflict; when poor villagers could not afford to help a neighbour; or when a loan to a neighbour was unable to be repaid. As one informant noted, "we have to be self-sufficient; we are not brave enough to ask for help, for instance, if we run out of salt, we can't ask the neighbour." 
Second, as the World Bank findings reported, villagers were less comfortable in more formal settings (Kecamatan Development Program 2006, 74), with participation rates lower for village meetings compared to customary (adat) and informal modes of organisation, which remain the key vehicles for social organisation. Yet, our interviews revealed that adat forms of organisation were delinked from processes of interest articulation: they managed resources or coordinated action within a limited scope - for example collective labour to repair irrigation channels or organise harvest festivals - but did not contribute substantially to solving village development issues. Third, our surveys and interviews also revealed that villages were socially differentiated along class and gender lines. Only a few individuals had strong vertical "bridging" relationships outside the village, into sub-district and district networks. These individuals - typically male landlords, moneylenders, village shopkeepers and the descendants of the old Acehnese chiefs (uleebalang) - took up key positions in village administration and with donor and state village programmes, mediating access to resources from the outside. Given that most villagers depended on these more powerful actors, they had limited scope to sanction them; and were therefore left open to exploitation and dependency. As we will see, many villagers resented the power of these actors; and given their inability to hold these actors accountable, many grievances festered and remained unaddressed. As noted above, the World Bank surveys of indicators of social capital concluded that Aceh's community-level social capital was strong (Kecamatan Development Program 2006, 72). Yet, the conclusion here is that despite apparent evidence of "social capital", given the strong inequalities and entrenched patterns of relational power, there was only limited potential for collective action to address poverty and vulnerability through the village based community development approaches deployed at this time.

Here chronic, persistent forms of poverty and vulnerability remain critical in what remains one of the poorest provinces in Indonesia (Waspada 2013). Aceh remains a place with pockets of very high vulnerability to food insecurity (World Food Program 2009). Earlier poverty assessments of Aceh differentiated the "structurally poor" from the "shocked": those whose poverty was linked to the impacts of the longstanding conflict and structural deficiencies in the Aceh economy on productive activities: and those driven into even deeper vulnerability due to asset loss after the tsunami (Aceh Poverty Assessment 2008). As we will see later, the problem in the tsunami affected regions was that short-term efforts to rehabilitate assets, and rehabilitate the livelihoods of the "shocked", did not always address the structural problems which re-emerged following the end of the economic stimulus of post-tsunami reconstruction. Indeed, surveys undertaken during this study, in sample villages in Aceh Besar eight years after the tsunami, reveal clear evidence of varying degrees of vulnerability and composite food insecurity among up to fifty per cent of households. ${ }^{2}$ As discussed elsewhere, the conflict and tsunami led to a shift in livelihoods on the west coast of Aceh: from a formerly diverse portfolio of activities (McCarthy 2006), to aid dependence during the immediate post-tsunami period (Thorburn 2010), and now to an overdependence on rice agriculture by mostly sharecropper farmers integrated into a highly uneven rural political economy, which remains subject to production failures (McCarthy, forthcoming). This is the context in which the posttsunami interventions took place.

\footnotetext{
${ }^{2}$ For reasons of space a deeper analysis of food security and vulnerability in post-tsunami Aceh is addressed elsewhere (McCarthy, unpubl. paper).
} 


\section{Post-tsunami interventions: Searching for project "success"}

Restoring productive assets and livelihoods constituted a key focus of recovery work in Aceh. Indeed, there was a "deluge of livelihood programmes", and these "were the facet of the recovery process most often encountered by households" (Thornburn, 2010: 91). These included cash grants or loans for enterprise development, and economic assistance in the form of livestock and agriculture programmes. ${ }^{3}$ As noted earlier, this research sought to identify "successful" projects - those that have more or less continued to provide livelihood benefits to villagers more than eight years after the tsunami. In other words, looking for success here meant trying to understand where we could find project engagements that supported more enduring forms of social action to address livelihood needs. Interviews in villages revealed donors had funded seven to ten of these livelihood development projects in each village, with most of these in each case engaging community led development approaches. In the two sub-districts, villagers only pointed to three salient donor sponsored activities that continue to function eight years after the tsunami. These are discussed below, alongside the ongoing World Bank initiated CDD and the communities' own efforts to mobilise the state.

(i) Reviving fisheries

In the past, Aceh's fisherman operated privately owned fishing platforms (palung) off the coast. Fishermen anchored their palung several kilometres off the coast, using lamps at night to attract the fish, and returned to the village each morning during the eastern monsoon to sell their catch. Each morning the palung owner received half the catch as his due, with the eight-member crew dividing the remaining 50\% among themselves. To ensure the palung succeeded economically, the operators monitored the profitably of their enterprise carefully; maintaining the platforms and fixing problems immediately if they emerged. The tsunami destroyed the palung. While sixty used to ply the coast, in 2012 fewer than twenty operated out of the key local fishing port.

As a palung costs up to Rp140 million, fishers were not able to rebuild them themselves, and several donors stepped in. A Singapore Red Cross funded project sponsored the construction of five palung by local builders, and at the time of this research, four of these remained in operation. ${ }^{4}$ Under this scheme, the main fishing village was to oversee the palungs' operation, with one palung to be oper-ated under each hamlet head. Timing here was the key: the project occurred much later, when fishers were returning to their livelihoods. At the time of research, the project had achieved a successful balance between benefits and responsibilities, and more effective institutional design. The palung heads were learning to fix problems as they emerged, and taking responsibility for maintenance. The key question remained whether an effective captain had emerged who could mobilise resources to protect the asset and sanction poorly performing fishers, similar to the role played previously by private owners.

Earlier, the Asian Development Bank funded the construction of six palung. Although there are several competing accounts of what occurred, ${ }^{5}$ according to a village leader the palung were left

\footnotetext{
${ }^{3}$ Thornburn (2010) estimates that approximately 12\% of all tsunami relief as of September 2007 had been devoted to livelihood projects.

${ }^{4}$ In the one case where the palung had failed, the captain failed to manage it well, and the palung ran at a loss and fell into debt. As the village had allocated the profits accumulated from fishing to other priorities, there was no budget set aside to fund its repair. It sat rotting on the wharf. Although the subdistrict head urged the other hamlets operating palung to fund its repair, this was yet to be agreed. Learning from this experience, another palung captain took a loan in his own name to repair his palung, and with the agreement of the village head deducted money from each catch to repay the loan.

${ }^{5}$ Several villagers alleged that the ADB contractor had failed to build the palung to local specifications,
} 
in disrepair on the wharf, and none remained operational. While ADB had granted the palung to a fisher cooperative, three other interventions by Oxfam and USAID, which involved setting up village cooperatives to manage palung in neighbouring villages, suffered a similar fate. During the period of aid dependence following the tsunami, fishermen were not ready to go back to their livelihoods. In the words of one interviewee, "At that time there was lots of aid flowing into the village, so people were still lazy, not thinking of working". In each case, villagers had either failed to maintain the palung, or experienced internal conflicts, or the cooperative had fallen into debt, leading to the palung either being abandoned, or to a decision by the village head to sell the vessel "rather than lose everything". In these cases, an inability to manage finances properly, horizontal conflicts within the cooperatives, and the failure to maintain the palung knocked the vessels out of action. With village-operated palung, it is less clear who owns the palung, and who is responsible for maintaining it. Even if ownership is vested in the village, decision-making is a long process, involving asking for permission from the village head, and lengthy deliberations in the village. Cooperatives under village ownership also depend on practices which are not established in the village, such as the transparency and accountability required to sustain an enterprise under collective control. Consequently, the cooperatives suffered from diffuse forms of accountability and enforcement, and there were incentives to shift profits to meet other village needs. In the unsuccessful cases, it remained unclear how the donors had provided for ongoing assistance and supervision.

The consequences for fishing livelihoods in Aceh were severe. A village leader estimated that only 136 of the 250 fishermen in his village had obtained a position on the palung. The other fishers had failed to gain access to either new palung, or to new boats and fishing equipment distributed during the reconstruction period. Several impoverished fishermen from other villages who were interviewed during the course of this research related how they remained "without a future", and now took to the sea on rubber tyres in an attempt to catch at least some fish - a remarkably poor outcome given the significant funds allocated for fisheries reconstruction.

(ii) The revolving livestock fund

Several projects developed community-based rotating cattle schemes. Under these schemes, the user group entrusts each individual with responsibility for one cow. After the cow gives birth, the villager keeps the offspring, and the parent animal rotates to another participant. This enables villagers without savings to develop assets that can be used in a time of need.

Heifter International developed a successful initiative in the village 2 area. One informant noted that out of dozens of NGO projects, this was one of the few still in operation: eight years later, four of the six revolving cattle groups are still extant. The head of the project was the descendent of the uleebalang (chief). During the post-tsunami period, donors recruited him to oversee several projects, all of which failed. As he noted, "assistance is often taken to be a gift for which people do not have to take responsibility, so that it is often sold or used for consumption". Farmers participating in a cattle group might say the cow had died, when they had sold it. Under his scheme, each farmer groups works together to develop a cowshed and to manage the cattle, with revolving credit activities and labour-sharing activities developed to support the livelihoods of members, according to agreements within the group. To ensure continuity, the project head developed a system of monitoring and supervision, with strict sanctions and incentives. Participants signed an agreement in front of the

using poor quality timber and ensuring that the palung could not go to sea for a prolonged period. The head of a neighbouring hamlet related that villagers were jealous, resenting that they had failed to win the contract to build the palung, and shifting the blame for its failure onto the contractor. 
police, which set out the scheme's rules. The head inspected barns to check that individuals were providing food, keeping their facilities clean, and caring for the cattle. If he found a farmer shirking on more than one occasion, the head confiscated and reallocated their cow. As members were forced to follow group regulations, this developed confidence in the institution and trust between members, and the continuity of these groups was ensured.

The project clearly mapped onto community structures and networks. It depended on the strong, asymmetrical power relationship and patron-client links associated with this capable but rather authoritarian leader. As a powerful local figure, he had extensive connections with government and outside NGOs, and was able to oversee training and facilitate agreements between participating farmers. Contrary to the "hippy model of community participation", 6 at times the head mobilised his inherited authority in a top-down fashion, initiating the sanctions which underlay the institutional arrangements that guaranteed the project's continuity. The head placed the continuity of the project above abstract principles of distributional and procedural justice. The head acknowledged that he would only select farmers whom he could trust. Farmers who were not participating complained that there was no transparency in the selection of group membership, noting that the participants who were selected tended to be those close to project leaders. A few farmers also complained that the regulation of the groups was too strict. However, focus group discussions revealed that in gene-ral, those who did join were happy with the groups. Although those excluded were bitter, they still hoped that the initiative would be extended to include them. Questions emerged regarding whether the groups had been captured by village elites, and whether the opportunity costs were too high for the poor; while farmers would benefit in the long term, in the short term they needed to find time to look after the cattle, and funds to contribute to running costs. However, in the two groups surveyed, approximately $70 \%$ were sharecroppers; suggesting that the poor were highly engaged in these groups.

In contrast, when FAO funded a cattle project in village 1, they faced the problem that Oxfam, the Red Cross and other agencies had provided cash grants to some of the villagers, to rebuild livelihoods. Villagers who had failed to receive cash grants demanded that the FAO cattle be provided as a grant, in lieu of the grants to which they claimed an entitlement. FAO acquiesced to these demands; thus, in this case village incentives and demands derailed this revolving savings scheme.

(iii) The micro-hydro project

Following the tsunami, a donor provided Rp 2.5 Billion to set up a micro-hydro project to supply electricity to villages in one of Aceh's subdistricts. To elicit participation, a cooperative was formed to own and to operate the generator. At the start there were 50 members who held meetings every three months. Initially, villagers received very cheap electricity, paying just a small fee to help repair the equipment. After the generator broke down, the electricity was now to be sold to the national grid to repay a loan that had been taken out by the project, and subsided electricity was no longer available. We conducted interviews with some poor villagers in the dark: they were unable to make these payments. In this case, the project fitted into existing power structures: villagers remained highly dependent upon the key village family, who meditated a range of economic opportunities. Despite formal monitoring and sanctioning mechanisms set out in state regulations governing cooperatives, there was no transparency or accountability downwards, and the project appeared to be have been appropriated by powerful village interests. Despite the participatory rhetoric articulated in the project website, villagers did not have a real sense of control or ownership. There

${ }^{6}$ Vajja and White 2008: 1148. 
were no clearly articulated entitlements or mechanisms for gaining access to benefits, nor did state institutions support the effective operation of the cooperative.

(iv) Social funding: the PNPM community driven approach

During this period, a World Bank supported community-driven development programme operated in this area, initially funnelling up to 8 billion rupiah $(\$ 880,000)$ per sub-district to address "the special needs in post-disaster areas" (Voss 2008). ${ }^{7}$ The programme provided a community-driven mechanism to identify, finance and implement small scale public investments. The object was to improve access to economic and social infrastructure and services among the poor, avoiding the weaknesses associated with the "top-down" investment planning typical of state agencies.

The National Community Empowerment Program (PNPM) also "aimed at accelerating poverty reduction" by "empower[ing] rural and urban communities to proactively participate in development" (PNPM support facility, 2008, 3). PNPM provided each sub-district with a block grant to fund small projects. PNPM also set up a deliberative mechanism, whereby communities identify priority projects and compete to have their project funded. After ranking project options according to programme criteria, a representative sub-district community committee selected the projects to be funded. Then individual villages received the funds to carry out activities - principally infrastructure development projects - under accountability procedures designed to avoid corruption. As the projects were identified and carried out by local communities, they sought to contribute to social capital formation and local community driven development.

A number of assessments have found that PNPM provides a better, more efficient way to allocate funds for building infrastructure; including providing employment opportunities which, as other studies found, increased consumption by up to 11 per cent (Voss 2008; McLaughlin et al. 2007). During interviews, several village leaders agreed with this proposition, arguing that PNPM provided an improved mechanism for decision making, delivering a system that allocated fund in response to village requests in contrast to the fickle state process. But field level interviews also revealed that project decision making clearly played into dysfunctional village networks and the crisis of trust that enveloped village government. Many villagers remained apathetic about the proposal development process: they saw it as dominated by elite aspirations and unlikely to provide significant assistance to ordinary villagers, with funding used opportunistically by powerful actors, and work opportunities awarded only to those close to the project facilitators. Given that individual survival in the village depended upon maintaining good relations with those mediating access to land and other livelihood opportunities, there were few channels to hold such actors accountable. ${ }^{8}$ This concurs with other assessments of social fund and community driven development processes,

\footnotetext{
${ }^{7}$ Initially known as the sub-district development programme (KDP), the programme was scaled up and rolled out on the national level as the National Program for Community Empowerment (Program Nasional Pemberdayaan Masyarakat or PNPM).

${ }^{8}$ In village 2, many villagers remained apathetic about the proposal development process because they saw it as dominated by elite aspirations, not able to provide significant assistance to ordinary villagers, and with funding used opportunistically by these powerful actors. Rather than have a conflict, it is better to withdraw." "There is no point in getting angry, we have to live in the kampung". The relationship between a vulnerable villager and the coordinator remained important for gaining access to work opportunities allocated under the tender, ensuring that those cultivating relations with this actor - a considerable section of the village - were afraid to mention this problem. Another village leader filled in the details: the coordinator did not pay those subcontracted to do the work until very late, and then not fully, i.e. not according to the wage rate set out beforehand. There were few channels to hold this actor accountable.
} 
which have found that these processes tend to be shaped by existing social relations, and that they are necessarily led, controlled and even captured by key actors (cf. Vajja and White 2008).

In an earlier assessment, Voss (2008) found that "despite an inclusive approach to community organising that seeks to bring all community members into the decision making process, the results indicated that disadvantaged groups are not benefiting". The marginalised included those with lower levels of education, female-headed households, and other disadvantaged groups, including the landless. ${ }^{9}$ Interviews revealed that the silence of the poor emerged from a combination of disempowerment, reticence and a lack of time. ${ }^{10}$ The transaction costs of participating in these CDD activities remained high, and for the most part only wealthier villagers could afford to stay involved. A number of informants alleged that discussions tended to occur during informal meeting involving the key villagers, often with one powerful actor effectively making the decisions. The fruit of these decisions are then brought to the general village meeting, when the proposal for submission to the programme was discussed. As PNPM projects provided facilitators, and an outside-directed process of guidance, monitoring and supervision, it worked much more effectively than other post-tsunami interventions. Nonetheless, the process was still clearly embedded in village networked space. When asked about this, the sub-district PNPM facilitator noted that, with so many villages to handle, it was beyond the capacity of the programme facilitators to overcome many types of problems. "If there are problems [in PNPM decision making and implementation of programmes], it's the responsibility of all sides, not just us; if the village is good, PNPM will go well; if the village is weak, it will be weak." Given the dependence of the project on functioning village networks dominated by powerful actors, he admitted that PNPM could not overrule governing structures: "If the facilitators openly take the side of the poorer people in the kampung, then the project does not succeed". Yet, as in other cases, this community based development led to debates, controversy and even demonstrations by villages regarding appropriate ways of spending the block grants. A key problem, as reflected in other studies, was that some villagers felt village needs and priorities insufficiently matched with the types of activities that could be implemented by this CDD programme (King et al. 2010).

The capacity of CDD activities to address poverty remains an open question, with critical studies suggesting that CDD plays only a minor role in assisting the chronic poor and more marginal groups (Rao and Ibdfiez 2003). In this case, as PNPM funds had to be spent on public goods and funds awarded to the villages in this survey were spent predominantly on small-scale village infrastructure, even though villages had already had extensive infrastructure built during the early post-tsunami period. One village leader argued that PNPM funds should instead focus explicitly on livelihood problems. He suggested that a lack of clear ideas among villagers, and an established practice of building infrastructure by actors who benefited from contracting, led to the misapplication of funds to unneeded infrastructure, such as improving the drains and gutters around the village. Assessment reports have noted that many problems emerged when the programme was scaled up to the national level (Akatiga 2010). In this case, the village head argued that PNPM

\footnotetext{
${ }^{9}$ PNPM provides for a bottom up, participatory planning process that aims to empower villages to plan for their own development needs. However, deliberative processes require the engagement of villagers, in order to understand the needs and potential of the village and work consciously through the processes of arranging the program.

${ }^{10}$ One villager noted that meetings take half a day, but then the activities "make little difference to the community economy". Another said that he had followed several steps in the PNPM process, however he chose not to join every night.
} 
activities required more effective facilitation, particularly because those making the decisions had insufficient understanding about the requirements of the poor. When asked about this, the subdistrict PNPM facilitator argued that although a facilitator might offer subtle suggestions, they could not state what a village required.

Ironically, in village 2, the control of the programme by powerful actors allowed for PNPM project funds to be bundled with other funds to support a livelihood related project: the extension of the irrigation system into the rice paddy. Here, the same powerful village actors against whom villagers had raised vocal complaints about arbitrary and self-serving behaviour, had advocated successfully on behalf of the village in PNPM subdistrict meetings. One village elder lamented the way in which the monies were controlled; however, given that the interests of landlords and poor sharecroppers were in alignment on this issue, he was happy that two billion rupiah would now be put into improving the irrigation channels, in the hope of increased production for both the poor and the village elite. However, he reserved judgement on the outcomes: "we need to see how this works out ... if people are serious it will work, but if it's manipulated, then something else will occur". In contrast, in village 1, where power relations were much more symmetrical and processes more participatory, village leaders had failed to use the CDD to address the key local developmental needs - that is, fixing the irrigation and developing a road to facilitate access to cash crop gardens - for the benefit of the poor. ${ }^{11}$

Since 2008, the PNPM programme also facilitated the coordination of business proposals by women: the granting and return of loans under a group-based micro-credit programme for rural women, known as Simpan Pinjam Perempuan or SPP. SPP provided one of few sources of capital in the village, and it specifically targeted women. To receive a loan under SPP, women were required to form a group and develop a credible business plan. Lenders were then obliged to make repayments every three months. Under a system of peer control, there were clear sanctions for participants. If one woman did not pay, the group had responsibility for meeting the repayment. The target of the SPP programme remained ensuring that loans flowed and that repayments accorded with the schedule. If repayments failed, the village would not receive SPP loans in the next period, and the flow of all provincial village development (BKPG) funds would cease.

The poorest women in the village were generally not participating in SPP. Poor women without secure livelihoods were hesitant to take the loans, because they were not confident they could make the repayment schedule. ${ }^{12}$ Women complained of a lack of guidance regarding where their

\footnotetext{
${ }^{11}$ In village 1, some of the key village actors' villagers felt that the priority should be irrigation development. However, one vocal villager opposed putting up irrigation for funding because most of the sawah was owned by landowners from outside the village, ensuring that the benefits of PNPM would not flow directly to resident villagers. The head of the farmer group remarked that the sawah was really kemukiman sawah - it belonged to farmers across the three villages - whereas PNPM grants were is decided upon at a village level, ensuring that it would be difficult allocated funds from one village's proposal to fix up the kemukiman sawah. The village secretary complained that proposals from the village failed to become a priority within the ranking process that determined how sub-district block grants would be spent. He regretted that village leaders were unable to advocate forcefully for village priorities. He felt that the programme framework was too rigid: while it provided for certain types of public goods, it would not accept proposals for building a place of worship for women or for constructing a road to village gardens - as these did fit the PNPM funding criteria. Dissatisfied with the programme, a group of villagers demonstrated outside the PNPM office. The problem here was that villagers did not accept PNPM criteria or the need to compete for funds - as they were forced to under PNPM - but rather saw PNPM funds as an entitlement.

${ }^{12}$ Several poor women interviewed during the project had initially taken out loans but later dropped out. We interviewed respondents who used the loans for productive purposes, petty trade, livestock development,
} 
business activities might best be channeled, and which markets they might develop, or indeed how money accessed through micro-credit schemes might best be used. Other assessments have drawn similar conclusions, noting that in the absence of clear ideas regarding income generating activities, businesses were often not viable; and that supporting activities to help with marketing or buying in bulk were absent. Consequently, women's groups were able to improve livelihoods in only a few cases (Akatiga 2010). ${ }^{13}$

(v) District development projects: using vertical networks

For villagers attempting to address critical developmental needs, a key alternative to available CDD related mechanisms remained scaling up - using vertical "bridging" connections up into the state to lobby for key resources. Following special autonomy, the Aceh district government had large amounts of funding available for rural development. However, according to the sub-district head, the disbursement of funds tended to be tied up in political disputes between the legislative and the executive. In this politically charged environment, where the focus remained infrastructure projects, projects tended to be exchanged for political favours. Here village leaders pointed to a lack of responsiveness from formal district government agencies to village vulnerability. ${ }^{14}$ While district government agencies had granted assistance, it tended to be sporadic: the district agricultural agency was yet to develop the capacity to deliver consistent programmes that addressed critical village livelihood needs.

In village 1, villagers wished to obtain funding to build a road, to facilitate access to market durian and revitalise their hillside gardens. While the village had repeatedly sought PNPM funds, the request had failed to gain the required support in the sub-district community deliberation process (MAD). Accordingly to one account, this was because the project was deemed so expensive and that it would require grants over several years. For three years, village leaders have failed to obtain funding via district planning meetings (musrenbang). Finally, a contractor with a timber interests across the province, a "son of the village" with large landholdings there, mobilised his social relations in the district assembly. The assembly allocated some funding for this road. Once again this worked because interests of villagers aligned with the interests of a powerful actor, who would thereby obtain access to the forest for logging and to develop an oil palm plantation.

In village 2 , the family descendent from the uleebalang focused on obtaining funds to build a road to facilitate access to the rice fields, as well as for a project to upgrade the irrigation system.

cake production or other household industries, or even buying agricultural inputs for their rice fields. However, given the lack of other sources of loans, we found respondents who had used funds to buy a fridge or to tile their floor. There appeared to be no sanctions if SPP funds were not used according to the proposal, or even if they were not used for productive purposes. Women noted that the main thing was to meet the procedural requirements of the organisers: for the loan to be repaid. It remained unclear to what extend PNPM succeeded in overcoming the vulnerability of marginal households who received SPP funds.

${ }^{13}$ A key weakness in this phase of the social fund implementation remained facilitation. The SPP programme funded several women to each set up a warung at the local waterfall. A group of ten women received a bridal makeup course and the provision of makeup equipment so that they could work as makeup artists in the advent of a village wedding. Given the number of warung already operating and that only three women had married the previous year, it remained unclear how these activities would generate a secure stream of income.

${ }^{14}$ As one key villager noted, "if we hope to get help from the government, then we will regret it. This is not going to work out. The government washes it hands; it is not thoroughly investigating what needs to be done to get agriculture working again. If government was thinking productively, he would come down and help work it out. But it is very difficult to build a bridge into the government". 
To this end, the son, who was also the village PNPM facilitator, invested in developing networks into political parties, joining the "team success" of the district head who was seeking election. As he noted, this was "the only way to score a goal". In the run up to elections, when the district head visited the area to attend a traditional feast, the district head accepted a proposal. A contract was given to a public works contractor, for a project to compact a road into the rice field, and to build a primary irrigation channel - all paid for from the district budget.

\section{Discussion}

While several projects were initiated in each village included in this study period, the research only found four continuing projects in the two sub-districts, eight years after the tsunami. In looking for "success", the research did find examples where incipient elements of collective action and adaptive capacity had emerged. The cattle project and the four surviving palung show that particular kinds of relationships can combine with capacity building activities, to support collective action toward addressing livelihood needs. These instances appear to have a contingent or serendipitous quality, in that they depended upon the presence of key contextual factors that may not be easily engineered by projects (King et al. 2010). Yet, certain conditions and patterns may make these particular outcomes more likely. Success was more likely to emerge when activities worked with accepted local authority structures, or mapped onto local power relations. Such outcomes required highly capable, committed leaders - prime movers capable of catalysing local organisations to develop rules to manage collective enterprises (Krishna 2007; King et al. 2010). Such leaders - or small groups of capable actors shaped projects to ensure that they mapped onto the local situational logic; including developing appropriate rules supported by locally accepted monitoring and enforcement mechanisms. Donor projects needed to provide space for this self-organisation, helping leaders to promote more sustainable outcomes and overcome collective action dilemmas, and avoid the problem of elite capture. As this takes time and resources, it implies ongoing support or monitoring by donors, and a capacity to work with state agencies over the long term (Gillespie 2004). Timing remained important in a second sense: successful outcomes tended to emerge only after the key actors had learnt from watching earlier failures. In contrast, short term success can be undermined by the perception of inequity, elite capture or even manipulation of schemes, affecting the prospects for successful collective action over the long term. While this required a degree of local legitimacy, successful processes might not necessarily meet donor preconceptions of equity and participation in processes and outcomes.

In many cases, donor projects achieved meaningful development outcomes (Brusset et al. 2009). Houses were built, and infrastructure and rice paddies reconstructed. For many individuals, grants proved of enduring value, with shop owners re-establishing their stock and reopening, and families obtaining livestock as grants from the Indonesian Red Cross during the reconstruction phase; and continuing to hold these valuable assets several years later. Yet, many of the projects which aimed to mobilise local participation to achieve enduring livelihood outcomes were less successful. To understand the reasons for this, we need to analyse the exigencies shaping donor practices; leading to, as one assessment report concluded, "inappropriate and poor quality programming" (Cosgrave 2007). For several reasons "allocation and programming ... were driven by the extent of public and media interest, and by the unprecedented funding available, rather than by assessment and need" (Telford and Cosgrave 2007). First, agencies involved in humanitarian aid systems tend to have little or unstable core funding, overlapping programmes and areas of work, and only partial coordination. At the same time, disasters remain critical for both fund raising and the profile 
of humanitarian agencies (Lyons 2009). These incentives led to particular practices. Agencies experienced pressure to be seen to deliver results, and this led quickly to competition between agencies and reduced coordination (Cosgrave 2007). As one evaluation report noted, the need to spend money quickly and visibly "led to many poorly executed aid projects and acted against the best interests of affected people" (Tsunami Evaluation Coalition n.d.: 2). Despite the PP/livelihood philosophy, there was a "poor understanding of context", and the PP template led to "stereotyped responses", sometimes leading to detrimental outcomes that increased inequality and jealousy (Tsunami Evaluation Coalition n.d., 15). Consequently, one report found "inappropriate and poor quality programming" (Cosgrave 2007). Noting an obvious contradiction between philosophy and practice, the authors concluded that agencies have agreed to standards and codes of conduct but had failed to meet them. Accountability to donors at home and the need to demonstrate outcomes to support further fund-raising campaigns make demonstrable success important, creating pressure to "build fast and furiously". ${ }^{15}$ There are no sanctions for failures: the public are unaware of any agency's work, so there is no push by customers for better quality. Although formal assessments of the needs of affected people were undertaken, these were "often not used, often not undertaken jointly, and not always shared" (Tsunami Evaluation Coalition n.d.: 3).

Interviews with villagers provide a more vernacular understanding of project outcomes. Villagers explained that the majority of surviving villagers were deeply depressed: "It is not that the aid wasn't of benefit ... but people here only began to think about their economy after they married ..., after they had children" ... "It was only last year" [2012, eight years after the tsunami], that "we began to think about the future". Given the large number of projects in the area, there were few incentives for villagers to follow any particular project. This meant that when a project offered assistance, many were passive or apathetic. As one villager indicated, agencies might take back the assistance, cancel or relocate it because it was not being used. "If it was left for three months, and we did not choose to continue it, rather than have a headache", he told one agency representative, "it would be better if you did not provide it".

With a large number of projects competing to elicit participation and disperse funds, there was little effective monitoring and supervision. Village leaders describe how some villagers were paid a wage to fix up their own rice paddy, taking the cash but not working on their own land, or using the money as a down payment on a motorcycle or other perceived need, rather than accumulating capital for reviving agricultural production as donors might have hoped. Collective action and cooperation were increasingly interest driven: actors might come together when it severed their interests, only to return to enduring kinship and neighbourhood that provided security (Cordaid and Eye on Aceh n.d.). As more than one villager noted, projects required a participating group of villagers to form a cooperative or user group. Funds were dispersed and activities arranged, but given that the project did not have a social base, the "project activity did not survive much beyond the photograph [of smiling villagers standing in front of the project facility or information board] taken by the agency before it withdrew". In other cases, villagers received grants in kind, such as an outboard motor or other equipment, only to sell on this "gift". "We were given seedlings, but at that time people weren't going to their gardens - they were still trying to sort out housing - so the seedlings died behind the house".

The outcomes of these projects can also be understood in relational terms. The formal village hierarchy and key influential figures, typically associated with village elite networks, became the

${ }^{15}$ ADB 2005a, quoted in Lyons 2009: 106. 
point of entry for donors and NGOs. Vocal and influential villagers described a rewarding period of intensive participation as advisors in implementing programmes. Mediating donor and NGO access provided these actors with material resources and livelihood programmes, and reinforced their status and power. These actors competed for access to donor activities, generating a culture of opportunism and completion. Given the lack of what might pass for transparent and democratic processes in a chaotic post-conflict/tsunami context, other villagers perceived that particular networks benefited disproportionately. As one subdistrict head noted, jealousies between beneficiaries with greater access to project benefits and those who felt excluded or disadvantaged led to rifts in networks. Those who were jealous became bitter, and it became normal for many villagers not to join village meetings, missing out on further opportunities. In this way, the interventions reinforced social and economic divisions, reinforced particular power structures while weakening competing networks, and thereby changing networked space in village (Cordaid and Eye on Aceh n.d.). One report from this period describes a "passenger psyche" or "culture of dependency" (Cordaid and Eye on Aceh n.d.). After donors had assessed village needs and designed their activities, many villagers simply sat and waited for aid to be delivered.

The intervention did affect patterns of collective action. Gotong royong is the key traditional vehicle for cooperation among villagers to attain shared goals - a form of generalised reciprocity where individuals help with the development or the repair of village facilities, or otherwise invest in collective goods, on the assumption that others will also extend help. Before the tsunami, villagers regularly used to participate. However, for several years post-tsunami, projects mobilised villagers with payments, and gotong royong was "severely affected by an attitude of no pay, no work" (Cordaid and Eye on Aceh n.d.: 18). While before people had never expected help from the outside and had limited cash needs, now villagers were consumers focused on addressing pressing cash needs; for example they only felt obliged to help clean and repair the mosque once or twice a year at the time of a major festival. Village social sanctions no longer functioned to support these forms of general reciprocity, which were largely broken down.

This fitted with a wider set of cultural changes. As one village noted, "before all were like family in the kumpung. Many people even married a distant cousin, and the village was "very intimate". "After the tsunami, village leaders are not so close. All have wives from the outside, and there are lots of personal interests". Further, village government had always depended upon elders with traditional authority (wibawa); old people with skill (cerdik pandai) in managing village affairs. With so many village elders having been swept away by the tsunami, village government fell into younger hands. As a result, there was less trust compared with before.

In many respects the interventions - together with other dynamics - changed the networks that once sustained village reciprocity and mutuality. For one informant, village marriages exemplified these changes: "Before when young people married, all would come. This occurs no longer, as that sense of sociality had been lost". Pointing to changing patterns of gotong royong, one Acehnese aid worker who had been heavily involved in post-tsunami work suggested that project interventions had degraded social capital.

In contrast to most post-tsunami interventions, PNPM provided systematic programme discipline - forms of guidance, support and control - that led to sustained engagement in the village. This provided for sustained improvements over state planning processes, offering opportunities for village learning and, where leaders could bundle PNPM with other developmental opportunities, 
some chances for pro-poor development. However, there were significant limitations: as other research on CDD projects have also found, marginalised groups had limited forms of participation in decision making processes, decisions were shaped by forms of relational power that worked against accountability, and villagers were fragmented or (due to the high opportunity and transaction costs of participation) lacked the capacity to develop proposals and lobby for funding. Alternatively, programme guidelines only provided for forms of public goods that had little impact on livelihoods. While project micro-credit schemes provided some women and their families with an adaptation strategy, many poor women opted out because of concerns they could not repay the debt, and nonrepayment amounted to being shamed in front of their peers. While the micro-credit might enable villagers to develop enterprises, many villagers were simply not in a position to choose the best economic option for a small business.

\section{Conclusion: Caught in a sad romance}

Over the last decades, concepts of livelihoods, capacities, and social capital have become central to the study of the complex factors leading to poverty. In this way, the focus has shifted to the total package of activities and resources at the disposal of rural households, focusing on the capacities and capabilities of the rural poor, rather than the problems besetting state programmes or the structural factors constraining local actors (Bebbington 1999). Such ideas purveyed a hopeful message: the rural poor can work to improve their situation by their own means. Similar assumptions underpin post-disaster interventions. Indeed, it is clear that the community based or driven approaches successfully stabilised a policy narrative, legitimised project interventions, mobilised support across a range of actors and successfully brought together resources and actors. They also provided a guiding theory, a template for project action, and a heuristic for interpreting outcomes. However, success in these terms may not extend to success in guiding implementation, or in representing field realities (Mosse 2005).

In particular, the transient nature of assistance, the kind of delivery mechanisms available, the exit strategies set into project planning as well as the need of donors and NGOs to produce success, and the lack of effective accountability relations in the field context, all worked to structure how projects worked at rebuilding livelihoods. In counterpoint to the romance of mobilising social capital, interventions were often not carried out in accordance with community led narratives. In the absence of effective guidance, support or control or enduring forms of accountability, projects did not provide incentives for continuity. Too often livelihood projects were abandoned after the donor surrendered them to "participants". ${ }^{16}$

It is useful here, following Pelling and High (2005), to distinguish between different dimensions of approaches to developing adaptive capacity. A first approach involves addressing the proximate causes, for instance by providing material resources to address the immediate disaster impacts, reviving livelihoods, engaging in short term livelihood programmes and infrastructure reconstruction, among other issues. It is here that the strengths of post-disaster approaches lay. A second approach involves supporting institutional modifications - attempting to change the balance of decisionmaking power, and the constraints to access resources for future adaptation and development. To be sure some interventions - such as those that attempted to develop community owned palung

${ }^{16}$ The key point here is that a particular post-disaster situational logic affected the modes of social action that occurred in networked space, influencing both what was desirable and achievable at a particular time. Villages had limited capacity to absorb the aid. As the workings of vertical and horizontal networks came into play, these relational dynamics shaped the forms of social action associated with the interventions. 
- tried this to some degree. However, interventions needed to "fit" with clearly identifiable local networks, structures and practices to get things done. Otherwise, projects that do not build on local networks would tend to fall over when the NGO staff withdrew. In the absence of long term investments, for the most part, projects could hardly modify the institutional logics on which they depended. Rather, interventions tended to reinforce existing patterns of social relations and power structures. Establishing a new logic of local institutional action would require engaging in the long term partnerships and capacity building, something beyond most donor timelines (Zanotti 2010).

A third, more transformative approach would involve engaging with the causal structure of vulnerability and poverty, by finding ways to link socio-economic development with a reduction in the vulnerability associated with the disaster and conflict (Ribot 2011; Bassett and Fogelman 2013). This type of transformative adaptation would entail identifying the processes producing vulnerability and where possible, redressing them. Immiseration occurred after the synergies between farming and other economic activity eroded, while agricultural production decreased sharply (McCarthy, forthcoming). The pathway to improvement entails investing in developing agricultural livelihoods and social protection systems, along with the revival of off farm working opportunities, and outmigration over the longer term. Unfortunately, CBD/CDD approaches were not aimed specifically at addressing these issues. Too often they attempted to assist the development of livelihoods, developing adaptive capacity without addressing the underlying causes.

An underlying problem is conceptual - community led approaches are based on a narrative sug-gested by an instrumental reading of the social capital literature: pre-existing forms of social cohesion can provide a basis for collective action to address critical needs. Given the depth of disruption and trauma, villagers may not be able to take up the position of participatory subjects or communities rich in social capital; nor was the logic of Acehnese social action well suited to participatory logics. As we have seen, despite superficial indications of social capital, individuals tend to address their vulnerability through individualised networks of reciprocity, or through vertical relations of dependence. The former tend to be highly differentiated, not always present among the very poor who may not be able to reciprocate within horizontal networks of reciprocity, or work against wider forms of collective action (Cleaver 2005). The latter are embedded in asymmetrical power relations that may disable attempts to institutionalise accountability, leading to jealousy and conflict in ways that ultimately undermine collective action.

A well-articulated critique of post-tsunami aid suggests that the solution to many of the problems raised by these interventions is more "local ownership" (Brusset et al. 2009). While there is some truth to this, given the contingent, context-specific nature of relational dynamics, the problem is more complex. Creating new participatory institutions from scratch may lead to a project being abandoned after the donor withdraws, particularly if the arrangements inadequately gel with how people organise themselves. But projects that use local networks may be subject to unaccountable and potentially exploitative social relationships. Where projects became opportunities for some actors, and are shaped by relational power dynamics and generate community fragmentation, projects can be captured by some networks or collapse under legitimacy problems. Yet, in other cases, elite control can be beneficial to poorer people: if dynamic leaders, willing and able to facilitate community-level projects and governance, adapt projects to pro-poor ends, or bundle elite interests with the interests of the poor, this can generate poverty alleviating outcomes.

Other readings of social capital suggest that effective outcomes can emerge from state-society synergy (Evans 1995; Adger 2003). However, following the conflict and tsunami, the Aceh context 
is characterised by state and civil society dysfunction and disorganisation. The strategy of the well-designed PNPM project studied here was one of avoiding the hard work of rebuilding formal state governance structures and processes and seeking to build networks and expand the space for collective action and the provision of public goods. As in other cases, well designed projects can engage with these networks and have a record of providing better outcomes than state based activities, especially in terms of developing village infrastructure (Sari et al. 2011). However, most assess-ments remain deeply ambivalent about participatory approaches that often lead to limited forms of empowerment and only marginally address poverty. This suggests that the build back better narrative that applies participatory approaches leads to a quandary. Attempting to build back better through $\mathrm{CBD} / \mathrm{CDD}$ approaches can leave donors and aid recipients caught in a sad romance: projects applying participatory narratives needed to act as if they were working to achieve outcomes even while the donor practices, situational logics and accountability relations mostly undermined successful community led outcomes. ${ }^{17}$

In conclusion, the policy implications are manifold. Donors and project interventions need to reassess assumptions and scale down ambitions. After reconstructing infrastructure quickly, intervention practices need to develop frameworks for addressing poverty over the longer term. While community based/driven approaches may be suited to particular objectives, such as building infrastructure, they are clearly not the only or necessarily the best tool for addressing vulnerability. Donors need to be less short-sighted and shift their gaze beyond the exigencies of disaster to make use of the proven strategies for responding to vulnerability (Devereuz, Vaitla, and Swan 2008). This entails turning back to developing long term solutions based on partnerships that engage local actors and the state more effectively to pursue longer term development.

John F. McCARThy lectures in the Australian National University's Crawford School. He carries out research into issues of agrarian change, land tenure, environmental governance, and natural resource policy. He is the author of The Fourth Circle: A Political Ecology of Sumatra's Rainforest Frontier (Stanford University Press, 2006); e-mail: John.mccarthy@anu.edu.au.

\footnotetext{
${ }^{17}$ Part of the problem is that vulnerability is to some extent embedded in uneven local social relations, and aid interventions depend upon these very same social relations to achieve their objectives (McCarthy, unpubl. paper).
} 


\section{Literature}

Akatiga 2010. Marginalized Groups in PNPM Rural. Akatiga - Centre for Social Analysis, Bandung.

Anderson, M. B. 2000. The Impacts of Natural Disasters on the Poor: A background Note, http:// siteresources.worldbank.org/INTPOVERTY/Resources/WDR/Background/anderson.pdf.

World Bank, 2005. Community Recovery through the Kecamatan Development Program. Jakarta, at www.multidonorfund.org/projects_kdp.php.

Bassett, T. J. and C. Fogelman 2013. Deja vu or something new? The adaptation concept in the climate change literature." Geoforum 48: 42-53.

Bebbington, A. 1999. Capitals and capabilities: a framework for analyzing peasant viability, rural livelihoods and poverty. World Development 27(12): 2021-44.

Blaikie, P. 2009. The tsunami of 2004 in Sri Lanka: An introduction to impacts and policy in the shadow of civil war. Geografisk Tidsskrift-Norwegian Journal of Geography 63(1): 2-9.

BRR 2009. Ten Management Lessons for Host Governments Coordinating Post-disaster Reconstruction. Executing Agency for Rehabilitation and Reconstruction (BRR) of Aceh-Nias 2005-2009, Jakarta.

Brusset, E., M. Bhatt, K. Bjornestad, J. Cosgrave, and A. Davies. 2009. A Ripple in Development? Long Term Perspectives on the Response to the Indian Ocean Tsunami 2004, at www. sida.se/publications.

Clarke, M., I. Fanany, and S. Kenny. 2010. Post-Disaster Reconstruction: Lessons from Aceh. London: Earthscan.

Cleaver, F. 2005. World Development. The inequality of social capital and the reproduction of chronic poverty 33(6): 893-906.

Cordaid and Eye on Aceh (n.d.). Missed opportunities post-tsunami aid and social capital in the reconstruction program of Cordaid in Aceh, www.cordaid.org/media/publications/Missed_ opportunities.pdf.

Cosgrave, J. 2007. Synthesis report: expanded summary, joint evaluation of the international response to the Indian Ocean tsunami. Tsunami Evaluation Coalition. London, alnap.org. i.e. www.alnap.org/pool/files/Syn_Report_Sum.pdf.

Evans, P. 1995. Embedded Autonomy. States and Industrial Transformation. Princeton, New Jersey: Princeton University Press.

Fox, J. A. 2007. Accountability Politics. Oxford: Oxford University Press.

Gillespie, S. 2004. Scaling up Community-driven Development: A Synthesis of Experience. Washington, DC: International Food Policy Research Institute.

Hickey, S. and G. Mohan. 2005. Relocating participation within a radical politics of development, Development and Change 36(2): 237-262.

Jayasuriya, S. K. and P. McCawley. 2010. The Asian Tsunami: Aid and Reconstruction After a Disaster, Asian Development Bank Instiute Edward Elgar Cheltenham 2010.

Kecamatan Development Program 2006. An Assessment of Village Infrastructure and Social Conditions. Jakarta, Ministry of Home Affairs, KDP Regional Management Unit in Aceh, World Bank Office Jakarta.

King, E., C. Samii and B. Snilstveit. 2010. Interventions to promote social cohesion in subSaharan Africa, Journal of Development Effectiveness 2(3): 336-370.

Krishna, A. 2007. How Does Social Capital Grow? A Seven-Year Study of Villages in India, Journal of Politics 29(4): 941-56.

Li, T. 2007. The Will to Improve: Governmentality, Development, and the Practice of Politics. Durham: Duke University Press. 
Lyons, M. 2009. Building Back Better: The Large-Scale Impact of Small-Scale Approaches to Reconstruction, World Development 37(2): 385-98.

McCarthy, J. F. 2006. The Fourth Circle. A Political Ecology of Sumatra's Rainforest Frontier. Stanford: Stanford University Press.

McCarthy, J. F. (n.d.), Food security and household vulnerability: towards a relational understanding (unpublished manuscript).

McLaughlin, K, A. Satu, and M. Hoppe. 2007. Kecamatan Development Program Qualitative Impact Evaluation, World Bank Office Jakarta.

Mosse, D. 2005. Cultivating Development: An Ethnography of Aid Policy and Practice. London: Pluto Press.

Nakagawa, Y. and R. Shaw. 2004. Social capital: A missing link to disaster recovery, Journal of Mass Emergencies and Disasters 22(1): 5-34.

Pelling, M. and C. High. 2005. Understanding adaptation: What can social capital offer assessments of adaptive capacity? Global Environmental Change 15: 308-319.

PNPM support facility. 2008. Progress report 2008. Technical Secretariat National Development Planning Agency. Republic of Indonesia, World Bank, Jakarta.

Rao, V. and A. M. Ibdfiez. 2003. The Social Impact of Social Funds in Jamaica. A MixedMethods Analysis of Participation, Targeting, and Collective Action in Community-Driven Development, The World Bank Policy Research Working Paper 2970.

Ribot, J. C. 2011. Vulnerability before adaptation: toward transformative climate action, Global Environmental Change 21(4): 1160-62.

Rigg, J. 2006. Land, farming, livelihoods, and poverty: rethinking the links in the rural South, World Development 34(1): 180-202.

Sari, Y. I., H. Rahman, and D. R. S. Manaf. 2011. Evaluation of PNPM Respek: Village Infrastructure and Institutional Development. Bandung, Akatiga - Centre for Social Analysis.

Telford J., Cosgrave, J. 2007. The international humanitarian system and the 2004 Indian Ocean earthquake and tsunamis, Disasters 31(1): 1-28.

Thorburn, C. 2010. Livelihood recovery in the wake of the tsunami in Aceh, Bulletin of Indonesian Economic Studies, 45(1): 85-105.

Vajja, A. and H. White. 2008. Can the World Bank Build Social Capital? The Experience of Social Funds in Malawi and Zambia, The Journal of Development Studies 44(8): 1145-68.

Voss, J. 2008. Impact Evaluation of the Second Phase of the Kecamatan Development Program in Indonesia, EASIS, The World Bank Indonesia.

WASPADA. 2013. Angka kemiskinan Aceh masih tinggi, 10/4/13, www.waspada.co.id; accessed 11/9/2013.

Woolcock, M. 2010. The Rise and Routinization of Social Capital, 1988-2008, Annual Review of Political Science 13: 469-87.

World Bank 2008, Aceh Poverty. Assessment 2008: The Impact of the Conflict, the Tsunami and Reconstruction on Poverty in Aceh, Jakarta.

World Food Program 2009. A Food Security and Vulnerability Atlas of Indonesia, Departement Pertanian RI and WFP, Jakarta.

Zanotti, L. 2010. Cacophonies of aid, failed state building and NGOs in Haiti: setting the stage for disaster, envisioning the future, Third World Quarterly 31(5): 755-71. 